\title{
HUKUM WARIS TERHADAP ANAK ADOPSI DALAM PERSPEKTIF ISLAM
}

\author{
Muhammad Lutfi Syarifuddin, SH. M.Hum \\ Sekolah Tinggi Agama Islam (STAI) Madiun \\ syarifuddin.lutfi@yahoo.com
}

\section{ABSTRAK}

In practice, in Indonesia children adoption has become a public phenomenon in society and is part of the family law system because it involves individual interests in the family. In the case of adoption, parents need to pay attention to the best interests of the child and be implemented based on local customs, applicable laws and regulations, this has been regulated in Article 39 of the Child Protection Act. Adoption of children is divided into two types, namely adoption of children between Indonesian citizens (domestic adoption) and adoption of Indonesian citizens by foreign citizens (adoption between countries). Appointment of children must be done by legal process, through the establishment or decision of the Court. The research method is normative juridical research. Based on the research results, the inheritance Indonesian citizens rights in the Indonesian inheritance law case are implemented based on Islamic law, adopted children do not inherit from adoptive parents and remain the biological parents. Under customary law, the inheritance of adopted children depends on customary law in the area. By law adoption children do not inherit from adoptive parents, and adopted children remain the heirs of their biological parents.

Keywords: Inheritance Law, Adopted Children, Islamic Law

\section{A. PENDAHULUAN}

Bagi orang tua, anak-anak adalah hadiah terbesar dari Allah swt. Selain 
itu, mereka adalah kekayaan yang lebih berharga daripada yang lain. Mereka sebagai kepercayaan kepada Allah yang harus terus dijaga dan dilindungi karena mereka memiliki martabat dan hak sebagai manusia yang harus dijunjung tinggi yang merupakan hak anak-anak. Ketika orang tua tidak memiliki anak dan telah membesarkan dan membesarkan anak-anak dengan semua cinta dan perhatian untuk waktu yang lama, sehingga mereka tumbuh secara fisik dan mental, maka mereka dianggap sebagai bagian dari keluarga mereka sendiri. Mereka dilindungi dari segala bentuk bahaya yang dapat mengancam kehidupan mereka, mereka diberikan pelukan cinta setiap saat sehingga anakanak menjadi belahan jiwa yang tidak dapat dipisahkan dari mereka.

Dalam Islam, adopsi anak yang diizinkan adalah adopsi yang tidak menempelkan nasab kepada anak-anak adopsi itu, sehingga posisinya tidak memengaruhi warisan. 1 Ini dapat dipahami dari ayat-ayat Al Qur’an, al Aḥzab ayat 37, di mana asbab al-nuzul dari ayat ini adalah ketika Nabi meminta oleh Allah untuk menikahi Zaynab yang notabene adalah mantan istri putra angkatnya, Zaid bin Harisah ${ }^{1}$. Islam tidak melarang seseorang atau keluarga untuk mengadopsi anak orang lain sebagai anaknya Anak itu disebut anak adopsi dan orang yang mengadopsi dia disebut orang tua adopsi ${ }^{2}$.

Dalam UU 1917 nomor 129 sebagai pedoman bahwa hanya anak lakilaki yang dapat ditunjuk sementara untuk anak perempuan secara eksplisit dinyatakan dalam pasal 15 ayat 2 bahwa "penunjukan anak perempuan dan adopsi dengan cara lain selain dengan membuat akta otentik adalah batal demi hukum karena hukum ". Pada tahun 1978 Surat Edaran Direktur Jenderal Hukum dan Perundang-undangan Kementerian Kehakiman No. JHA.1 / 1/2 dikeluarkan 24 Februari 1978 yang mengatur prosedur adopsi anak-anak Indonesia oleh orang asing ${ }^{3}$. Secara umum, setiap anak memiliki hak dan kewajiban sebagai anak dalam keluarga, tetapi hak anak sering diabaikan karena kondisi keluarga yang tidak memungkinkan. Berdasarkan hal ini, menjaga anak-anak miskin dan terlantar adalah salah satu tugas pemerintah. Ini telah ditulis dalam UUD 1945 Pasal 34 ayat (1), yang berbunyi "anak-anak miskin dan terlantar dirawat oleh Negara". Salah satu upaya untuk

${ }^{1}$ Mifa Al Fahmi,. Warisan Anak Angkat Menurut Hukum Adat dan Kompilasi Hukum Islam. Jurnal Hukum USU Volume 5 No. 1: 1 (2017)

Yasin. Titik Temu Hukum Waris di Indonesia. Yogyakarta: Idea Press (2011)

3 Diah Triani Puspita Sari,. Implementation of Adoption Arrangements After the Enactment the Goverment of Indonesia Number 54 of 2007, Indonesia University, pp 19 (2010) 
menciptakan kesejahteraan anak diatur dalam Pasal 12 ayat (1) dan (3) Undang-Undang Nomor 4 Tahun 1979 tentang Kesejahteraan Anak, yaitu melalui adopsi anak. Dalam Pasal 12 ayat (1) undang-undang menetapkan bahwa adopsi anak untuk kepentingan kesejahteraan anak yang dilakukan di luar bea cukai, dilakukan berdasarkan peraturan perundang-undangan ${ }^{4}$.

Dalam Undang-Undang Nomor 23 Tahun 2002 tentang Perlindungan Anak, itu tidak merumuskan pemahaman tentang adopsi. Tetapi itu hanya merumuskan makna anak adopsi, yaitu Pasal 1 angka $9^{5}$ menyatakan bahwa:

"Anak adopsi adalah anak yang haknya ditransfer dari lingkungan keluarga orang tua, wali sah, atau orang lain yang bertanggung jawab atas perawatan, pendidikan, dan membesarkan anak, ke lingkungan keluarga orang tua angkat berdasarkan keputusan atau keputusan pengadilan".

Sedangkan untuk definisi adopsi anak dirumuskan dalam Peraturan Pemerintah Nomor 54 Tahun 2007 tentang Implementasi Penunjukan Anak dalam Pasal 1 angka 2 menyatakan bahwa:

"Penunjukan anak adalah tindakan hukum yang memindahkan anak dari lingkungan otoritas orang tua, wali yang sah, atau orang lain yang bertanggung jawab atas perawatan, pendidikan, dan membesarkan anak ke dalam lingkungan keluarga orang tua angkat "

\section{B. METODE}

Jenis penelitian yang digunakan oleh peneliti adalah penelitian hukum normatif atau penelitian hukum perpustakaan, yaitu penelitian hukum yang dilakukan dengan memeriksa bahan pustaka atau sekunder yang terdiri dari sumber penelitian bahan hukum primer, bahan hukum sekunder, dan bahan hukum tersier. Materi-materi ini disusun secara sistematis, ditinjau, lalu ditarik kesimpulan sehubungan dengan masalah yang diteliti. Studi hukum memiliki beberapa pendekatan. Dengan pendekatan ini, peneliti akan mendapatkan informasi dari berbagai aspek masalah yang dicoba untuk menemukan jawabannya. Pendekatan yang digunakan dalam penelitian adalah pendekatan

${ }_{4}$ Fransiska Hildawati Tambunan, Tinjauan Yuridis dalam Penunjukan Anak-anak Warga Negara Indonesia Oleh Warga Negara Asing (Adopsi Antar Negara), Universitas Negeri Semarang, halaman. 3-4.(2013)

5 Ahmad Kamil dan M. Fauzan. Undang-Undang tentang Perlindungan dan Penunjukan Anak di Indonesia. Jakarta: PT Raja Grafindo Persada (2010) 
hukum statuta (statute approach) ${ }^{6}$. Terkait dengan pendekatan hukum yang penulis gunakan, dilakukan dengan memeriksa semua hukum dan peraturan yang berkaitan dengan masalah hukum yang sedang dipelajari, di mana penelitian ini dilakukan untuk menentukan kesesuaian dan perbandingan antara undang-undang yang digunakan, hasil penelitian nantinya akan digunakan sebagai argumen untuk menyelesaikan masalah hukum atau masalah yang dihadapi. Sifat penelitian ini sejalan dengan sifat ilmu hukum itu sendiri. Ilmu hukum memiliki sifat sebagai ilmu preskriptif, artinya merupakan ilmu preskriptif, hukum mempelajari tujuan hukum, nilai-nilai keadilan, keabsahan aturan hukum, konsep hukum dan norma hukum.

Dalam Hukum Perdata serta Hukum Islam yang biasanya digunakan untuk menjelaskan masalah warisan, dinyatakan bahwa anak adopsi tidak termasuk dalam diri seseorang pewaris ${ }^{7}$. Namun, dalam perspektif lembaga adat, penentuan hak waris untuk anak adopsi tergantung pada hukum adat yang diatur. Bagi keluarga yang memegang prinsip orang tua, di Jawa, misalnya, adopsi tidak secara otomatis memutus hubungan keluarga antara anak dengan orang tua kandung. Karena itu, selain memperoleh hak waris dari orang tua angkatnya, anak-anak juga masih memiliki hak waris dari orang tua kandungnya. Di sisi lain, di Bali, adopsi seorang anak dianggap sebagai kewajiban hukum untuk membebaskan anak dari keluarga asalnya untuk memasuki keluarga angkatnya. Anak menjadi anak biologis dari orang yang membesarkannya dan melanjutkan posisi orang tua angkatnya.

\section{HASIL DAN PEMBAHASAN \\ 1. Keberadaan Warisan}

Kata pewarisan berasal dari bahasa Arab, mirāth. Bentuk jamak adalah mawārith yang berarti warisan orang mati, yang akan dibagikan kepada semua ahli waris. Syarat-syarat warisan adalah studi tentang bagaimana pembagian warisan sesuai dengan syariah Islam. Studi mawārith juga disebut Studi Farāid ${ }^{8}$.

Dalam Hukum Waris Islam, ada tiga alasan bagi orang untuk mendapatkan

${ }^{6}$ Peter Mahmud Marzuki,. Riset Hukum. Jakarta: Grup Media Kencana Prenada (2007)

7 Abu Hapsin, Bagaimana Menjadikan Hukum Islam Sebagai Kebijakan Hukum Negara Indonesia: Argumen Konstitusi dan Sosiologis. Al-Ahkam 27, tidak. 2 (2017) pp140-41. (2017)

${ }^{8}$ Tim Penyusun Depag. Fiqih. Jakarta: Departemen Agama. (2002) 
bagian dari warisan, di antaranya: kekerabatan, perkawinan, dan kerabat. Ada alasan lain mengapa orang mendapatkan warisan, karena wala '. Jika seorang pria membebaskan seorang budak, akan ada hubungan kekerabatan di antara mereka yang disebut wala 'al-'itq. Dengan adanya hubungan semacam itu, pria itu akan mewarisi budaknya yang telah membebaskannya, untuk berjaga-jaga. budak sama sekali tidak memiliki ahli waris, baik karena hubungan perkawinan atau kekerabatan (Wahyuni, 2018). Namun, saat ini, alasan warisan karena wala telah kehilangan makna secara signifikan. Karena pada saat ini tidak ada perbudakan Ria, 2008). Ada tiga unsur yang perlu dipertimbangkan dalam pewaris dan warisan: (1) kekayaan warisan (mawrūth); pewaris atau orang-orang yang meninggalkan warisan (muwarrith); dan ahli waris. Sementara itu, ada tiga persyaratan warisan, di antaranya9: pertama, kematian ahli waris. Ini berarti kematian karena kematian sesungguhnya, hukmi (sesuai keputusan hakim) dan taqdiri (konon). Tanpa kepastian tentang kematian ahli waris, kekayaan warisan tidak boleh dibagikan kepada ahli waris. Kedua, kehidupan pewaris. Harus jelas kapan pewaris meninggal. Ini karena seorang pewaris menjadi pengganti untuk mengontrol warisan yang ditinggalkan oleh pewaris. Transfer kekayaan diperoleh melalui proses pewarisan. Jadi setelah pewaris meninggal, pewaris harus benar-benar hidup. Ketiga, mengetahui status warisan. Agar ahli waris dapat mewarisi kekayaan, harus ada hubungan yang jelas antara keduanya, seperti: hubungan orang tua-anak, hubungan suami-istri, dan hubungan saudara, baik saudara kandung, ayah yang sama atau ibu yang sama. Selain itu, harus diperhatikan apakah ada kendala pewarisan atau tidak.

Dalam Hukum Waris Islam, ada tiga kendala yang diwariskan: pertama, menjadi budak. Seorang budak tidak menerima warisan karena semua kekayaannya adalah milik tuannya. Jika kita memberikan warisan dari kerabatnya, itu akan secara otomatis menjadi miliknya. Ini berarti bahwa ada warisan kepada orang lain tanpa alasan ${ }^{10}$. Kedua, pembunuhan. Para ulama Hanafiyah membagi dua jenis pembunuhan, pembunuhan langsung (mubāsharah) dan pembunuhan tidak langsung (tasabbub). Pembunuhan langsung dibagi menjadi tiga: pembunuhan yang disengaja, pembunuhan yang disengaja, dan pembunuhan yang tidak disengaja. Pembunuhan tidak langsung, seperti sese-

\footnotetext{
9 Moh. Muhibbin, \& Abdul Wahid. Hukum Kewarisan Islam sebagai Pembaruan Hukum Positif di Indonesia. Jakarta: Sinar Grafika.

${ }^{10}$ Abu Malik Kamal, Tuntunan Praktis Hukum Waris: Lengkap dan Padat Menurut Al-Qur'an dan As-Sunnah yang Shahih. Jakarta: Pustaka Ibu Umar (2009)
} 
orang membuat lubang di kebunnya, maka ada orang yang jatuh ke lubang itu dan mati. Kematian korban karena apa yang tidak secara langsung dilakukan oleh orang yang membuatnya. Menurut ulama Hanafiyah, pembunuhan langsung adalah halangan untuk diwariskan, sedangkan pembunuhan tidak langsung tidak. Ketiga, agama berbeda. Agama yang berbeda berarti agama pewaris berbeda dari agama pewaris. Hal ini didasarkan pada perkataan Nabi, "Seorang muslim tidak bisa mewarisi kekayaan kafir dan dia tidak mampu mewarisi kekayaan muslim". (HR. Bukhari Muslim) ${ }^{11}$

\section{Fenomena Adopsi Anak}

Definisi anak adopsi menurut UUD RI Nomor 35 Tahun 2014 adalah anak yang haknya ditransfer dari keluarga orang tua, wali hukum, atau orang lain yang bertanggung jawab atas perawatan, pendidikan, dan membesarkan anak menjadi adopsi keluarga orang tua berdasarkan keputusan pengadilan. Menurut Pasal 171 Kompilasi Hukum Islam, anak adopsi adalah anak yang diasuh dalam kehidupan sehari-hari, biaya pendidikan dan sebagainya, dan tanggung jawab beralih dari orang tua kandung ke orang tua angkatnya. berdasarkan keputusan pengadilan.

Ketentuan pasal ini secara implisit menekankan bahwa adopsi seorang anak menyebabkan pemindahan tanggung jawab dari orang tua kandung kepada orang tua angkatnya dalam hal merawat kehidupan sehari-hari, biaya pendidikan dan sebagainya, sedangkan nasab hubungan, wali nikah untuk anak adopsi, dan hak-hak warisan dari orang tua kandung tidak dilanggar (Musthofa, 2008). Dalam Islam adopsi sah dari seorang anak tidak menempelkan nasab pada adopsi anak sehingga tidak mempengaruhi pernikahan atau mahram dan warisan. Dapat dipahami dari al-Ahzab ayat 37, di mana asbabun nuzul adalah ketika Nabi diperintahkan oleh Allah untuk menikahi Zaynab yang merupakan mantan istri dari putra angkatnya yang bernama Zayd bin binarisah.

Adopsi anak adalah tindakan positif dalam hukum adat kami dengan berbagai motivasi, sesuai dengan keragaman sosial dan bentuk kekerabatan di Indonesia. Konsekuensi dari adopsi anak yang sah adalah munculnya hukum perdata seperti mata pencaharian, pengasuhan anak dan warisan antara anak

${ }^{11}$ Fikri dan Wahidin. Islam dan Hukum Waris Adat: Analisis Kontekstualisasi Dalam Masyarakat Bugis. Al-Ahkam: Jurnal Ilmu Syariah Dan Hukum Volume 1 No. 2 (2016) pp 199. 15 
yang diadopsi dan orang tua angkat ${ }^{12}$.

Undang-Undang Nomor 23 tahun 2002 tentang Perlindungan Anak menyatakan dengan tegas bahwa tujuan dan motivasi anak adopsi dapat dilakukan hanya untuk kepentingan terbaik anak dan didasarkan pada kebiasaan setempat dan ketentuan hukum dan peraturan yang berlaku. Praktek mengadopsi anak, dengan motivasi komersial untuk perdagangan manusia atau hanya untuk provokasi memiliki anak maka anak adopsi diabaikan, sangat bertentangan dengan hak-hak bawaan anak.

Padahal, adopsi anak di Indonesia memiliki sejumlah tujuan dan motivasi. Salah satu tujuannya adalah untuk melanjutkan garis keturunan jika dalam sebuah keluarga tidak memiliki anak. Motivasi ini sangat kuat untuk pasangan menikah yang telah dihukum karena tidak bisa mendapatkan anak/ tidak mungkin untuk melahirkan anak karena beberapa alasan, seperti infertilitas. Padahal mereka sangat menginginkan kehadiran anak dalam keluarga mereka ${ }^{13}$. Dengan demikian adopsi anak adalah tindakan positif dalam hukum adat kita dengan berbagai motivasi yang ada, sesuai dengan keragaman masyarakat dan bentuk kekerabatan di Indonesia. Staatblad 1917 No. 219 menetapkan bahwa konsekuensi hukum dari adopsi adalah sebagai berikut: (a) Pasal 11: Anak yang diadopsi secara hukum memiliki nama keturunan para adopter. (b) Pasal 12 ayat 1: anak adopsi dibuat sebagai anak yang lahir dari orang yang mengadopsi. Akibatnya, anak angkat menjadi pewaris orang yang mengadopsi.

Sementara itu, menurut hukum Islam, anak adopsi tidak diakui sebagai dasar dan penyebab pewarisan, karena prinsip utama pewarisan adalah hubungan darah atau arham. Namun, pada kenyataannya, di banyak tempat di mana orang-orang beragama Islam, masih ada dan mengatur adopsi di mana anak adopsi dapat mewarisi kekayaan orang tua angkat. Bahkan, karena kecintaan mereka pada anak adopsi, pewarisan sudah berjalan sejak pewaris masih hidup ${ }^{14}$.

${ }_{12}$ Susiana. Hak Anak Adopsi Menuju Warisan Orang Tua Adopsi, Kanun Jurnal Ilmu Hukum Volume 13 No. 55 (2011) pp 140-42.

${ }^{13}$ Mutasir. Dampak Hukum Pengangkatan Anak pada Masyarakat Desa Terantang Kec. Tambang Kabupaten Kampar Ditinjau dari Hukum Islam, Jurnal An-Nida Volume 41 No. 2 (2017) pp 177-78

${ }^{14}$ Hilman Hardikusuma, Hukum Waris Adat. Bandung: Citra Aditya Bakti (2015) 


\section{Posisi Anak Adopsi}

Aturan anak adopsi yang basa digunakan adalah perspektif Hukum Adat yang mengadopsi anak orang lain ke dalam keluarga mereka sedemikian rupa sehingga antara orang yang mengadopsi anak dan anak adopsi memiliki kekerabatan, seperti yang terjadi antara orang tua dan anak kandung mereka sendiri. Anak-anak yang diadopsi memiliki hak dan kewajiban tertentu terkait dengan posisinya dalam struktur keluarga itu, seperti menggunakan nama keluarga yang disebut marga atau klan, memiliki hak untuk menikmati fasilitas keluarga, dan harus tetap merawat dan membantu ${ }^{15}$.

Islam mengakui bahwa adopsi adalah hal yang mulia karena sama dengan membantu anak-anak yang membutuhkan bantuan, terutama anak yatim. Namun demikian, harus dipahami bahwa ada batasan tertentu yang harus dipatuhi dan tidak harus dilanggar. Misalnya, karena tidak memengaruhi mahram mereka, maka tidak diperbolehkan ketika anak-anak yang sudah dewasa diperlakukan sebagai anak mereka sendiri. Namun, mereka bukan mahram orang tua.

Adopsi anak mengikuti proses formal Hukum Adopsi Adopsi. Hal ini dapat dianalisis dari Putusan Mahkamah Agung No. 210 / K / Sip / 1973 bahwa untuk melihat validitas anak adopsi tergantung pada pelaksanaan upacara adat, tanpa secara objektif memeriksa keberadaan anak dalam kehidupan keluarga orang tua angkatnya Persyaratan penerimaan anak adopsi dapat dilihat dari Keputusan Mahkamah Agung Republik Indonesia. Nomor 912 K / Sip / 1975 yang menyatakan bahwa tanpa melalui prosesi upacara adat, adopsi anak tidak sah meskipun ia telah dibesarkan sejak kecil dan menikah oleh orang tua angkatnya.

Seiring perkembangan Hukum dan keadilan yang tumbuh di masyarakat, gagasan ini telah berubah dengan munculnya gagasan baru untuk mengidentifikasi seseorang apakah ia anak adopsi atau tidak, tidak hanya bergantung pada adopsi sebagai formalitas, tetapi juga yang sudah ada kenyataan kepada siapa dia telah dirawat, disunat, disekolahkan, dan menikah. Hal ini sejalan dengan Putusan Mahkamah Agung Nomor 53 K / Pdt / 1995 pada 18 Maret $1996^{16}$. Motivasi untuk adopsi anak dalam hukum adat berbeda dari motivasi untuk adopsi anak dalam UU Perlindungan Anak. Karena itu menekankan

${ }^{15}$ Abdurrohman.Kasdi, Konseling Perkawinan sebagai Upaya Membangun Keluarga Sakinah; Model Pembinaan dan Pendampingan Keluarga Sakinah di Kabupaten Demak, Jurnal Konseling Religi Volume 10 No. 1 (2019) pp 99-115

${ }^{16}$ Reggena Purba,. Hukum Adat dalam Yurisprudensi, Varia Peradilan Volume 20 No. 260 (2007) pp 38-46 
bahwa tindakan adopsi hukum harus didasarkan tidak hanya pada kepentingan terbaik anak. Dalam hukum adat, lebih menekankan pada kepedulian calon orangtua angkat akan kepunahan mereka, maka mereka (pasangan yang tidak memiliki anak) membesarkan seorang anak dari kerabat keluarga yang melakukannya secara sukarela. Akibatnya, anak-anak tersebut memiliki posisi sebagai anak sendiri dari orang tua angkat dan ia terpisah dari keluarga sebelumnya.

Adopsi anak oleh KHI tidak mempengaruhi status anak adopsi. Jika anak-anak bukan milik mereka sendiri, maka itu tidak dapat diwarisi dari orang tua yang telah membesarkan mereka. Menurut KHI, adopsi anak hanya dapat diizinkan jika telah memenuhi ketentuan, termasuk tidak memutus hubungan anak dengan orang tua kandung. Selain itu, posisi anak adopsi bukan sebagai pewaris orang tua angkatnya, anak adopsi tidak menggunakan nama orang tua adopsi secara langsung, orang tua adopsi tidak dapat menjadi wali nikah anak angkatnya ${ }^{17}$.

Di antara konsekuensi hukum adopsi adalah tentang status anak adopsi adalah sebagai pewaris orang tua angkatnya. Menurut KHI, anak yang diadopsi tidak dapat secara legal menjadi dasar dan penyebab warisan, karena prinsip dasar dalam Hukum Warisan Islam adalah memiliki hubungan darah / nasab / keturunan. Ini berarti bahwa adopsi menurut KHI tidak membawa dampak hukum terhadap status anak adopsi. Jika mereka bukan anak orang tua mereka sendiri, maka mereka tidak dapat mewarisi dari orang tua angkat mereka, tetapi hubungan pewaris masih dari orang tua kandung, serta hubungan nasab.

Hukum Adat umumnya mengambil anak berdasarkan kebiasaan yang memiliki kesamaan dan / atau pengakuan kekerabatan dengan orang tua angkatnya dan memutuskan hubungannya dengan orang tua kandungnya. Dalam hal posisi anak adopsi sebagai pewaris kekayaan warisan orangtua adopsi, pada dasarnya semua informan penelitian menyatakan bahwa anak adopsi tidak termasuk dalam kategori ahli waris. Karena itu, pada dasarnya, anak adopsi tidak mewarisi warisan ayah angkat mereka. Namun, dalam uraian tentang warisan secara umum, bahwa anak adopsi adalah posisi sama sebagai anak-anak kandung, mereka masih berhak mendapatkan warisan. Informan penelitian ini menggunakan teori konflik sederhana di mana UU diperlukan ketika konflik terjadi dalam distribusi warisan. Ini berarti bahwa

${ }^{17}$ Fauzi. Konsep Patah Titi: Masalah Warisan dan Solusinya di Aceh Tengah, Studia Islamika Volume 26 No. 1 (2019) pp 44-46. 
ketika tidak ada konflik di mana semua anggota keluarga setuju untuk memasukkan anak adopsi sebagai ahli waris, maka tidak ada masalah dalam hal itu. Pengecualian lain terhadap posisi anak adopsi sebagai ahli waris adalah ketika orang tua adopsi tidak memiliki anak kandung.

Diharapkan bagi orang yang akan mengadopsi anak untuk melakukan proses secara resmi ke Pengadilan Negeri sehingga keberadaan anak semakin kuat dan adopsi tidak hanya karena alasan belum memiliki keturunan, tetapi didasarkan pada cinta dan memiliki kesejahteraan anak. Orang tua yang akan mengadopsi anak, memahami prosedur dan proses adopsi anak sesuai dengan ketentuan ajaran Islam ${ }^{18}$.

Hak Waris dari Anak yang Diadopsi dalam hukum Islam, antara anak adopsi dan orang tua adopsi tidak ada hubungan warisan. Karena itu, posisi anak adopsi sangat lemah dalam hal ini, terutama jika ia tidak memiliki surat resmi terkait adopsi. Di sisi lain, fakta kadang-kadang tidak terbalik di mana anak adopsi mengendalikan semua warisan orang tua adopsi. Dengan alasan itu, ia telah banyak membantu mengadopsi orang tua. Kedua fenomena ini kemudian menciptakan masalah hukum waris yang menjadi wewenang Pengadilan Agama. Islam mengajarkan sistem kekerabatan berdasarkan ajaran agama dan sesuai dengan kondisi keluarga. Ini menentukan hak dan kewajiban anak serta batasan berdasarkan ajaran Islam. Islam juga meningkatkan tradisi adopsi dan mengambil kembali hubungan nasab dengan penyebab-penyebab esensial, seperti hubungan darah antara orang tua dan anak-anak. Hubungan ini adalah hubungan perasaan dan sopan santun. Itu tidak memiliki konsekuensi dan kebutuhan biasa seperti mewarisi satu sama lain dan membayar diyat yang semuanya merupakan konsekuensi dari hubungan darah. Hal ini dilakukan agar anak adopsi tidak bebas dan diabaikan tanpa ikatan sama sekali dalam keluarga setelah hubungan adopsi anak dihapuskan. Nash ini "... dan jika Anda tidak mengenal ayah mereka ..., dapat menggambarkan betapa kacaunya institusi keluarga pada masa jahiliyyah dan inilah yang ingin diperbaiki dan dibenarkan oleh Islam dengan membangun sistem keluarga di atas dasar hubungan orang tua biologis dan juga dengan membangun sistem komunitas berdasarkan prinsip-prinsip keluarga yang sehat, aman dan benar.

Konsekuensi hukum dari adopsi menurut hukum adat adalah variatif, itu berarti bahwa itu mungkin berbeda dari hukum adat dari satu daerah ke daerah lain. Misalnya, dalam hukum adat Minang, meskipun adopsi anak

${ }^{18}$ Susylawati, Eka. Penerapan Hukum Waris Islam Dalam Perkara Waris di Pengadilan Agama Pamekasan, Al-Ihkam Volume 9 No. 2 (2014): 326-27. 
adalah tindakan yang diizinkan, peristiwa ini tidak menyebabkan konsekuensi warisan antara anak yang diadopsi dan orang tua yang mengadopsi. Sementara itu di daerah yang mengadopsi sistem kekerabatan bilateral (parental), seperti di Sulawesi, Jawa dan Kalimantan, adopsi anak memiliki konsekuensi warisan. Menurut adat Jawa, ada istilah ngangsu sumur loro untuk menggambarkan warisan anak adopsi. Kata ngangsu berarti mencari, sumur berarti air atau sumur, dan loro berarti dua. Prinsip ini menegaskan bahwa anak-anak adopsi mewarisi dari dua sumber, dari mengadopsi orang tua dan orang tua kandung ${ }^{19}$.

Kompilasi Hukum Islam menekankan bahwa antara orang tua angkat dan anak adopsi, tidak ada hubungan warisan, tetapi sebagai bentuk pengakuan terhadap lembaga adopsi, hubungan mereka dikonfirmasi oleh wasiat wajibah (akan), untuk membedakannya dari posisi ahli waris, pengaturan anak adopsi ini diatur dalam bab V KHI tentang wasiat. Wasiat adalah salah satu bentuk kepemilikan kekayaan yang dikenal dan diakui dalam hukum Islam, di samping bentuk kepemilikan lainnya. Praktek wasiat telah dikenal sejak lama sebelum Islam datang, tetapi dalam praktiknya, tidak memiliki aturan yang jelas. Pada saat itu, semua orang bebas memberikan asetnya kepada siapa pun yang dia inginkan, tanpa pengawasan dan peraturan yang mengaturnya ${ }^{20}$.

\section{KESIMPULAN}

Hukum Islam jelas seperti yang disebutkan di atas di mana posisi mengadopsi orang tua hanya dalam tanggung jawab merawat, biaya pendidikan dan lebih banyak lagi yang ditransfer ke orang tua adopsi sehingga tidak sama dengan anak kandung dalam hal warisan atau nasab. Hak-hak waris anakanak yang diadopsi menurut hukum adat berbeda-beda, itu berarti bahwa satu daerah memiliki hukum adat yang berbeda dengan yang lain. Menurut masalah warisan, ada juga variasi dalam ketentuan hukum, dalam hal hak waris, ada berbagai ketentuan. Karena adopsi, itu menyebabkan hubungan warisan antara orang tua adopsi dan anak adopsi dan memutus warisan anak adopsi dengan orang tua kandung mereka. Ada juga alasan adopsi anak hanya sebagai janji temu tanpa hak waris. Bahkan, karena adopsi anak, hubungan warisan dengan anak angkat dan orang tua kandung masih ada dan hubungan warisan anak adopsi dengan orang tua kandung muncul karena adopsi anak.

\footnotetext{
19 Rachmad Budiono, Pembaruan Hukum Kewarisan Islam di Indonesia. Bandung: Citra Aditya Bakti (1999)

20 ibid
} 
Sementara itu, hak waris anak adopsi menurut Kompilasi Hukum Islam, tidak ada hubungan pewarisan antara anak adopsi dan orang tua angkat mereka. Adopsi anak-anak dalam hukum Islam terbatas pada kesejahteraan, menjaga anak-anak adopsi dari kelalaian, sehingga hubungan antara anak-anak adopsi dan orang tua kandung mereka masih tetap. Ketentuan surat wasiat diatur dalam pasal 209 Kompilasi Hukum Islam yang mengatur bahwa untuk orang tua angkat yang tidak menerima surat wasiat, diberikan surat wasiat wajib sepertiga dari warisan anak adopsi dan untuk anak adopsi yang tidak menerima surat wasiat diberikan surat wasiat wajib dari warisan orang tua angkatnya. Hukum di Indonesia adalah pluralisme. 


\section{DAFTAR PUSTAKA}

Ahmad Kamil, M. Fauzan. Undang-Undang tentang Perlindungan dan Penunjukan Anak di Indonesia. Jakarta: PT Raja Grafindo Persada, 2010.

Al-Fahmi, Mifa. "Warisan Anak Angkat Menurut Hukum Adat dan Kompilasi Hukum Islam." Jurnal Hukum USU 5, no. 1 (2017): 1.

Budiono, Rachmad. Pembaruan Hukum Kewarisan Islam di Indonesia. Bandung: Citra Aditya Bakti, 1999.

Fauzi. "Konsep Patah Titi: Masalah Warisan dan Solusinya di Aceh Tengah." Studia Islamika 26, no. 1 (2019): 44-46.

Hapsin, Abu. "Bagaimana Menjadikan Hukum Islam sebagai Kebijakan Hukum Negara Indonesia: Argumen Konstitusi dan Sosiologis." Al -Abkam 27, no. 2 (2017).

Hardikusuma, Hilman. Hukum Waris Adat. Bandung: Citra Aditya Bakti, 2015.

Kamal, Abu Malik. Tuntunan Praktis Hukum Waris: Lengkap dan Padat Menurut Al-Qur'an dan As-Sunnah yang Shahih. Jakarta: Pustaka Ibnu Umar, 2009.

Kasdi, Abdurrohman. "Konseling Perkawinan sebagai Upaya Membangun Keluarga Sakinah; Model Pembinaan dan Pendampingan Keluarga Sakinah di Kabupaten Demak." Jurnal Konseling Religi 10, no. 1 (2019).

Marzuki, Peter Mahmud. Riset Hukum. Jakarta: Grup Media Kencana Prenada, 2019.

Moh.Muhibbin, \& Abdul Wahid. Hukum Kewarisan Islam sebagai Pembaruan Hukum Positif di Indonesia. Jakarta: Sinar Grafika, n.d.

Musthofa. Pengangkatan Anak Wewenang Pengadilan Agama. Jakarta: Kencana Prenada Media Group, 2008.

Mutasir. "Dampak Hukum Pengangkatan Anak pada Masyarakat Desa Terantang Kec.Tambang Kabupaten Kampar Ditinjau dari Hukum Islam." Jurnal An- Nida 41, no. 2 (2017).

Pasal 1 Ayat 9 Undang-Undang RI Nomor 35 Tahun 2014 tentang Perubahan Undang-Undang. n.d.

Pasal 171 Kompilasi Hukum Islam (KHI). n.d.

Peraturan Pemerintah Nomor 54 Tahun 2007 tentang Implementasi Penunjukan Anak. n.d.

Purba, Reggena. "Hukum Adat dalam Yurisprudensi." Varia Peradilan 20, no. 
260 (2007).

Ria, Wati Rahmi. Aspek Yuridis Tentang Hukum Waris Islam. Universitas Lampung, n.d.

Sari, Diah Triani Puspita. Implementation of Adoption Arrangements After the Enactment the Goverment of Indonesia. Indonesia University, 2010.

Susiana. "Hak Anak Adopsi Menuju Warisan Orang Tua Adopsi." Kanun Jurnal Ilmu Hukum 13, no. 55 (2011).

Susylawati, Eka. "Penerapan Hukum Waris Islam Dalam Perkara Waris di Pengadilan Agama Pamekasan." Al-Ihkam 9, no. 2 (2014).

Tambunan, Fransiska Hildawati. Tinjauan Yuridis dalam Penunjukan Anakanak Warga Negara Indonesia Oleh Warga Negara Asing (Adopsi Antar Negara). Universitas Negeri Semarang, 2013.

Tim Penyusun Depag. Fiqih. Jakarta: Departemen Agama, n.d.

Wahidin, Fikri dan. "Islam dan Hukum Waris Adat: Analisis Kontekstualisasi Dalam Masyarakat Bugis. Al-Ahkam." Jurnal Ilmu Syariah Dan Hukum 1, no. 2 (2016).

Wahyuni, Afidah. "Sistem Waris dalam Perspektif Islam dan Peraturan Perundang-Undangan dii Indonesia."' Salam: Jurnal Sosial Dan Budaya Syar'i 5, no. 2 (n.d.).

Yasin. Titik Temu Hukum Waris di Indonesia. Yogyakarta: Idea Press, 2011. 